\title{
Violence against doctors: before and during the pandemic of COVID-19
}

\author{
Karpaga Priya, Vineet K. Pathak*
}

Department of Community and Family Medicine, All India Institute of Medical Sciences, Raipur, Chhattisgarh, India

Received: 15 July 2020

Revised: 06 September 2020

Accepted: 08 September 2020

\section{*Correspondence:}

Dr. Vineet Kumar Pathak,

E-mail: pathakvineet2089@gmail.com

Copyright: ( $)$ the author(s), publisher and licensee Medip Academy. This is an open-access article distributed under the terms of the Creative Commons Attribution Non-Commercial License, which permits unrestricted non-commercial use, distribution, and reproduction in any medium, provided the original work is properly cited.

\begin{abstract}
Work-place violence has been on rise in recent years. Hospitals and medical fraternity are not spared of it either. Initially there were instances of such acts in hospitals only. The health care professionals are not spared even on fields as evidenced by recent attacks on frontline workers who are involved in contact tracing and screening amid Severe acute respiratory coronavirus 2 (SARS CoV2). In order to find the different causes leading to violence against doctors and to recommend solutions for them, relevant articles published in last five years in English language from India were included. High patient load, lack of necessary facilities, insufficient number of trained staff are few of the drawbacks of our hospital setting. While long waiting hours, delays in referrals, high out of pocket expenditure are troubling issues from a patient's perspective. In view of the rising pandemic, stigmatization, fear of isolation are few reasons giving rise to such events. In order to curb such workplace menace and to deliver health services at peace, there is a dire need for controlling such ruthlessness. The medical council, hospital administration, government and media, all have an indispensable role to make doctors feel safe and to furnish smooth services. Incorporation of critical communication in syllabus, increasing specialty seats for emergency medicine, strengthening pre-hospital services, changing the setup of emergency room are the need of the hour. With the recent amendment to Epidemic disease Act, 1897 offering protection to frontline workers, there is a light towards the end of tunnel.
\end{abstract}

Keywords: Workplace violence, Doctors, COVID-19, Safe practice

\section{INTRODUCTION}

Workplace violence is defined by the World Health Organization (WHO) as incidents where staffs are abused, threatened or assaulted in circumstances related to their work, including commuting to and from work, involving an explicit or implicit challenge to their safety, well-being or health. ${ }^{1}$ The numbers of such violence against doctors have been on a rise and are not uncommon in India. From verbal abuse to grievous injuries, the medical fraternity across the globe have experienced it all. ${ }^{2}$ A study conducted by Indian Medical Association has found that $75 \%$ of doctors have faced some form of violence at work. ${ }^{3}$ Beginning with verbal abuse, verbal threats to physical threats and assaults not sparing vandalizing the hospital properties, the hospital sector has faced it all.

\section{BEFORE THE PANDEMIC}

A recent assault on junior doctors in one of the government hospitals of West Bengal, India has stirred the doctors' community to despair medical practice. A 75-year-old respectable gentleman was brought into the Emergency room (ER) and was immediately attended by the doctors. Unfortunately, the patient passed away because of a sudden cardiac arrest. It was followed by a mob of the deceased's relatives attacking the doctor which lead to a grievous injury culminating in the death of the doctor.

\section{CHALLENGES}

The doctor patient ratio in India hasn't satisfied the recommendations yet. ${ }^{4,5}$ According to Rural health 
statistics, there is a shortfall of 3244 doctors in Primary Health centers (PHC), reflecting the government's lackadaisical attitude of non-recruitment against the vacant positions. ${ }^{6}$ There is an annual intake of 67,218 Bachelors of medicine and bachelor of surgery (MBBS) graduates per year. But the total number of post graduate seats available are around 35,736 (MD/MS/DNB/ Diploma). Among these, only 73 Doctor of medicine (MD) seats and 136 Diplomate of national board (DNB) seats are available in the branch of Emergency medicine. ${ }^{7}$ The emergency and trauma center are usually high emotional flow areas and hence violence against doctors are found to be higher in these places. $^{8}$ The number of doctors attending an emergency case and the number patients needing attention tend to remain disproportionate. This leads to long waiting hours and inadequate communication. Here begins the gap between the doctor and patients' attenders. A few ER are facing infrastructural deficiencies and improper human resource management. At times it happens that the ER tends to be a waiting area for patients until they are transferred to another department. Long waiting hours, lack of emergency investigations, inordinate delay in referral, extremely crowded conditions of the ER and wards are few among the other igniting reasons. ${ }^{9,10,11}$ Media and internet have seeded negative perspectives about health system among population. At times, a patient might not be saved despite the best medical care. It is when the attenders' pent up emotions tend to break out as a violent act.

\section{RECOMMENDATIONS}

\section{Role of medical council}

The art of critical communication should be incorporated in the curriculum and the medical students should be given hands on training for the same. For communication skill training, instructive methods (seminars, lectures) are less effective compared to experimental methods like role plays, videos, simulating doctor-patient interaction. ${ }^{12}$ Expanding emergency medicine as a standalone branch for effective delivery of services.

\section{Role of hospital administration}

A live digital board displaying the availability of beds in ER and Intensive care unit (ICU) should be placed at the entrance of the hospital to enable the attenders in deciding a prior, so that once the primary care is delivered the attenders would be ready to transfer the patient to another hospital. The pre-hospital staff should work hand in hand with the ER staff.

There should be strong round the clock security at three levels as shown in Figure 1.

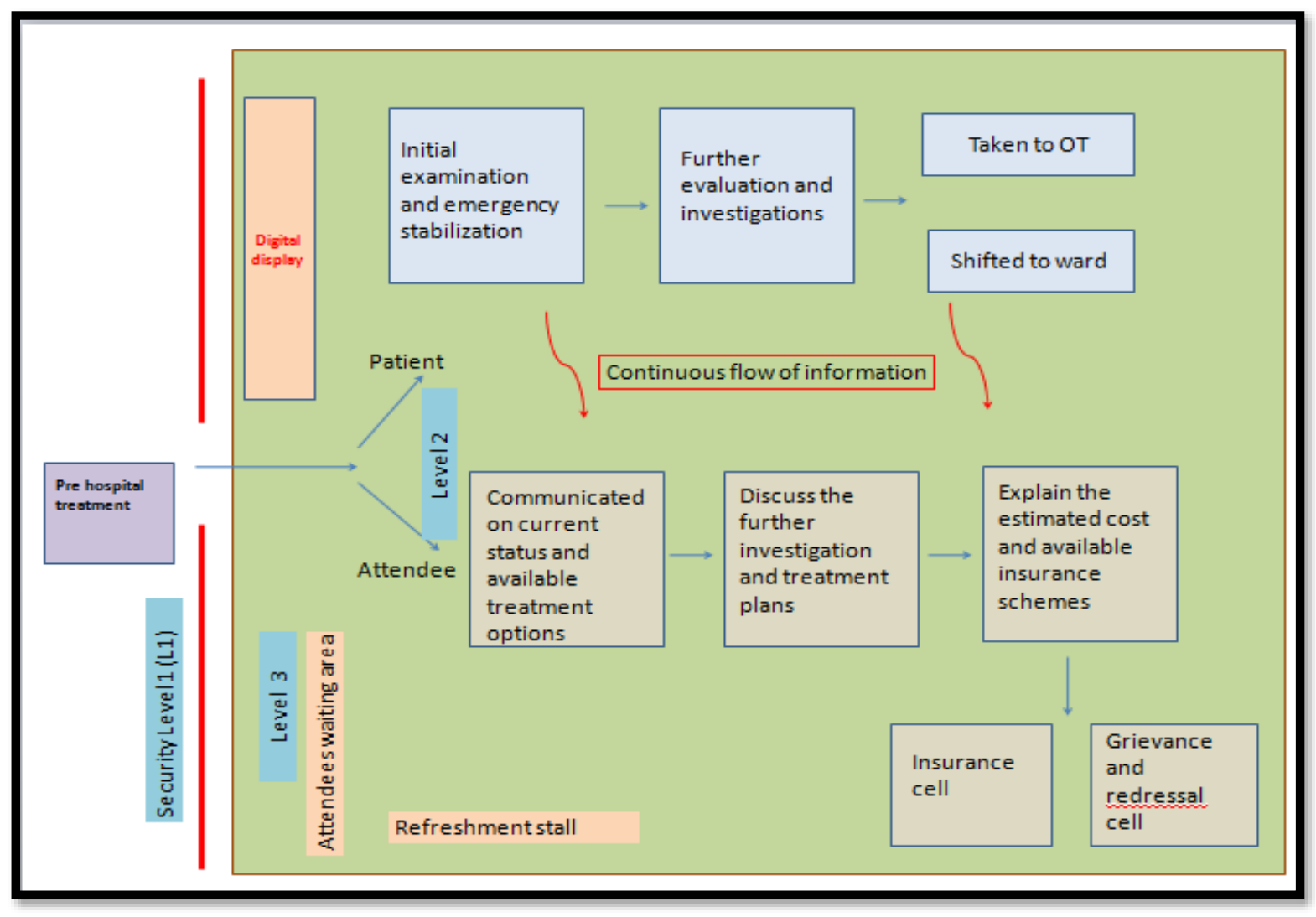

Figure 1: New ER setup model. 


\section{Regulations and enforcements}

Hospitals should have a functional insurance cell with timely approval of patients' bills. Government should initiate steps to enact a strict law for the security of doctors with rigorous punishments.

\section{Role of media}

Mass media should refrain from making such medical mishap issues into matter of sensations for private gains. The main focus should lie on improving the health care delivery system with faster and better utilization of resources. When the communication gap is bridged and the patient's attendees are given equal respect and attention as the patient, there is light towards the end of the tunnel for safer work-place environment for doctors and health care workers.

\section{During the pandemic}

The emerging viral SARS CoV2 in India has been spreading rapidly and taking huge toll of lives. In order to contain the spread, government has taken a lot of initiatives. Contact tracing and community screening of suspect cases are few among the many. While in the process of protecting the public, the health care professionals and police force have faced a lot of hassles. A few to highlight are the violence attacks at Indore, Bhopal Gaswani village and attacks inside hospital of Hyderabad, Ghaziabad. ${ }^{13,14,15}$ When the healthcare staff, police force and sanitary workers are fighting the virus, risking their own lives and families protecting the public, the public are fighting these saviors.

\section{A light at the end of tunnel}

Promulgation of an Ordinance to amend the Epidemic Diseases Act, 1897 in the light of the pandemic situation of COVID-19. ${ }^{16}$

- The current ordinance is intended to ensure that during any situation akin to the current pandemic, there is zero tolerance to any form of violence against healthcare service personnel and damage to property.

- Violence as defined in the ordinance will include harassment and physical injury and damage to property.

\section{Who is covered under this ordinance?}

Healthcare service personnel include public and clinical healthcare service providers such as doctors, nurses, paramedical workers and community health workers; any other persons empowered under the Act to take measures to prevent the outbreak of the disease or spread thereof; and any persons declared as such by the State Government, by notification in the official gazette.

\section{When can it be invoked?}

In instances of damage to property including a clinical establishment, any facility identified for quarantine and isolation of patients, mobile medical units and any other property in which the healthcare service personnel have direct interest in relation to the epidemic.

What is the punishment?

- Acts of violence are cognizable and non-bailable offences.

- Offenders are punished with imprisonment for a term of three months to five years, and with fine of Rs.50,000/- to Rs.2,00,000/-.

- In case of causing grievous hurt, imprisonment shall be for a term six months to seven years and with fine of Rs.1,00,000/- to Rs.5,00,000/-.

- In addition, the offender shall also be liable to pay compensation to the victim and twice the fair market value for damage of property.

How fast are the judgments passed?

Offences shall be investigated by an officer of the rank of Inspector within a period of 30 days, and trial has to be completed in one year.

\section{CONCLUSION}

A peaceful and prosperous country can be established only with its healthy population. There is a shared responsibility between the general public and the doctor's community. Though violence against doctors is on rise, specially, as witnessed during the pandemic times, they continue to provide their service. The amendments brought out in this Epidemic disease act is likely to provide a safe environment for the doctors and other health care workers to render their duties. With multiple sector coordination and a separate legislation ensuring the health care workers' secure environment, more efforts are needed to reduce the violence in future.

Funding: No funding sources

Conflict of interest: None declared

Ethical approval: Not required

\section{REFERENCES}

1. WHO. Workplace Violence. WHO, World Health Organization. Available at: https://www.who.int/violence_injury_prevention/inj ury/work9/en/index2.html. Accessed on 4 May 2020.

2. Violence against doctors: A viral epidemic? Reddy IR, Ukrani J, Indla V, Ukrani V. Indian J Psychiatry. Available at: http://www.indianjpsychiatry.org/ article.asp?issn=00195545; year $=2019$; volume $=61$; is sue $=10$; spage $=782 ;$ epage $=785$; aulast $=$ Reddy. Accessed on 4 May 2020. 
3. Over $75 \%$ of doctors have faced violence at work, study finds. India News - Times of India. The Times of India. Available at: https://timesofindia.indiatimes.com/india/Over-75of-doctors-have-faced-violence-at-work-studyfinds/articleshow/47143806.cms. Accessed on 4 May 2020 .

4. India, Data. Available at: https://data.worldbank.org/country/india. Last accessed on 4 September 2020.

5. Chapter1. Available from: http://www.cbhidghs.nic.in/WriteReadData/1892s/B efore\%20Chapter1.pdf. Accessed on 4 May 2020.

6. Kumar R, Pal R. India achieves WHO recommended doctor population ratio: A call for paradigm shift in public health discourse! J Family Med Prim Care. 2018;7(5):841-4.

7. College and Course Search. MCI India. Available at: https://www.mciindia.org/CMS/informationdesk/college-and-course-search. Accessed on 4 May 2020.

8. Ambesh P. Violence against doctors in the Indian subcontinent: A rising bane. Indian Heart Journal. 2016;68(5):749-50.

9. Ghosh K. Violence against doctors: A wake-up call. Indian J Med Res. 2018;148(2):130-3.

10. Nagpal. Incidents of violence against doctors in India: Can these be prevented? Available at: http://www.nmji.in/article.asp?issn=0970258X; year $=2017$; volume $=30$; issue $=2$; spage $=97$; epa ge $=100 ;$ aulast $=$ Nagpal\#ref10. Accessed on 4 May 2020.

11. Chauhan V, Galwankar S, Kumar R, Raina SK, Aggarwal P, Agrawal N, et al. The 2017 Academic College of Emergency Experts and Academy of Family Physicians of India position statement on preventing violence against health-care workers and vandalization of health-care facilities in India. Int $\mathbf{J}$ Crit Illn Inj Sci. 2017;7(2):79-83.
12. Teaching and Assessing Communication Skills in Medical Undergraduate Training. ResearchGate. Available at: https://www.researchgate.net/publication/30388016 5_Teaching_and_Assessing_Communication_Skills _in_Medical_Undergraduate_Training. Accessed on 4 May 2020.

13. Lives at stake: Karnataka doctors protest attacks by Covid patients' kin. Hindustan Times. 2020. Available at: https://www.hindustantimes.com/indianews/lives-at-stake-karnataka-doctors-protestattacks-by-covid-patients-kin/story-

fV8qtbPftFltSBgbWmDc5J.html. Accessed on 4 May 2020.

14. Ravi R. Abused, Attacked, Beaten: Frontline Workers Are Risking Their Lives Everyday In India. 2020. Available at: https://thelogicalindian.com/news/covid-19healthcare-workers-attacked-20665. Accessed on 4 May 2020.

15. Attacks On Doctors, Healthcare Workers Rise Amid COVID-19 Pandemic. NDTV.com. Available at: https://www.ndtv.com/india-news/attacks-ondoctors-healthcare-workers-rise-amid-covid-19pandemic-2204547. Accessed on 4 September 2020.

16. Promulgation of an Ordinance to amend the Epidemic Diseases Act, 1897 in the light of the pandemic situation of COVID-19. Available at: pib.gov.in/Pressreleaseshare.aspx?PRID=1617327. Accessed on 4 May 2020.

Cite this article as: Priya K, Pathak VK. Violence against doctors before and after the pandemic of COVID-19. Int J Community Med Public Health 2020;7:4189-92. 